\title{
Obituaries
}

\section{Sir Walter Gurner, C.S.I.}

Born on 18th January, 1888, Cyril Walter Gurner was educated at Merchant Taylors' School, Oriel College, Oxford, and University College, London. Having passed the Indian Civil Service examination in 1910 he was posted to Bengal and spent his career there. In 1918 he was appointed Deputy Chairman of the Calcutta Corporation and from 1925 to 1929 served there as Secretary to the Local Government Department. In 1940 he became Special Officer in the Revenue Department, and in 1943 Special Officer in the Public Health Department. In 1946 he was knighted.

Retiring in 1947 he was until 1951 a Regional Controller, Ministry of Town and Country Planning. Joining this Society in 1921 he was a frequent reviewer of works on Sanskrit and twice served as a valued member of its Council. He died on Sunday, 14th August, 1960.

\section{J. S. Furnivall}

Born in 1878, John Sydenham Furnivall was educated at Epsom School and Trinity Hall, Cambridge. Having passed into the Indian Civil Service he served in Burma from 1902 until 1925. On retirement he settled with his Burmese wife in Rangoon and interested himself in adult Burmese education, opening a bookshop and organizing the translation of European works into Burmese. In 1939 after studying at Leyden and visiting Indonesia he produced his Netherlands India : a Study of Plural Economy, and in 1948 was published his Colonial Policy and Practice. In 1936 Cambridge appointed him Lecturer in Burmese. From 1948 until 1960 he served an independent Burma as Adviser to the Minister of Planning at Rangoon. He died at Cambridge, aged 82.

\section{H. Sт. J. В. РhILby, 1885-1960}

The death of H. St. J. B. Philby in Beirut on the 27th September, 1960 , has robbed the Society of one of its oldest members (he joined in 1909, and served on the Council for a year in 1920) and of a most distinguished personality. 
Born in 1885, he was educated at Westminster and Trinity College, Cambridge, and then entered the Indian Civil Service. In 1915 he was posted to Mesopotamia and thus made his entry into the Arab world which was to be the scene of his work and interests for the rest of his life. Profound and sincere disagreement with British official policy towards the Arabs led to his resignation from government service in 1925, and he was thereafter a free-lance. Never again did he submit himself to the bonds of any official position, and his considerable achievements were entirely the result of personal qualities. The fascinating story of his relations with King 'Abdul 'Aziz, and of his political influence, has been told in the obituaries in the daily press. Here, it is more suitable to recall his contributions to science and scholarship.

Always passionately addicted to travelling, he acquired in his long career an overall intimacy with the Arabian peninsula such as no other European, and probably only a handful of Arabs, have achieved. To his travels he brought the eye of an acute observer able to register every detail of significance. And the fruits of these observations were made available to the world in a series of monumental works (The Heart of Arabia, 1922 ; The Empty Quarter, 1933 ; Sheba's Daughters, 1939; Arabian Highlands, 1952; The Land of Midian, 1957) which are an absolute mine of information on almost every aspect of the peninsula-flora and fauna, geology, sociology-and in the field of cartography in which he has made a lasting contribution to science. In another direction, his personal acceptance of Islam and his long and intimate acquaintanceship with King 'Abdul 'Aziz, enabled him (in Arabia of the Wahhabis, 1928 ; Arabian Jubilee, 1952 ; Sa'udi Arabia, 1955) to give accounts of the rise of Wahhabism and the fortunes of the Sa'udi dynasty, which as historical source-material are not likely to be superseded.

It was during a trip in the southern deserts in 1936 that he seems first to have encountered the South Arabian inscriptions which to an increasing extent became the focus of his personal interests in the latter part of his life. His travels resulted in a vast contribution to our material in this field and he himself was keenly interested in its evaluation. It must be conceded that in the last-named aspect of his work he was not invariably successful : he had a yearning for clear-cut solutions and was impatient of the somewhat negative suspension of judgment so often unavoidable when one is faced with insufficient data. His methods sometimes recalled the 
reasoning of Peacock's Mr. Asterias, "Might it not be a mermaid ? It was possibly a mermaid. It was probably a mermaid. Nay, what else could it be but a mermaid ? It certainly was a mermaid " (a form of argument, the seduction of which the most eminent scholars have not always been able to resist). His first essay in interpreting the pre-Islamic history of Arabia, "The Background of Islam " (Alexandria, 1947), must be accounted a failure; it is too full of fantastic and untenable hypotheses. But it was written under difficulties, in the war years when he had no access to books and was cut off from contacts with other scholars in the field. In recent years, he was fully aware of this, and had been hoping to produce a completely revised edition. And he has the merit of having (in his article "South Arabian Chronology", Le Muséon, 1949) been the first to raise a voice against an unsound preconception vitiating the work of experts in this field: namely the idea that South Arabian kingship was to be visualized in terms of a continuous series of father-to-son successions like the better-established European monarchies.

Those who knew him will not forget his personality : a commanding one, sometimes almost overpowering, but always characterized by true humanism and abounding kindness. For two things above all his memory will be cherished : his abundant hospitality and his generous encouragement of younger men. He was never so happy as when acting the genial host, dispensing a truly Arabian hospitality to a gathering of friends. And of his encouragement of the young, I myself have been a beneficiary since, in 1937, he entrusted to me, unknown and untried as I was, the exciting task of editing the inscriptions gathered in his journey of the previous year.

Bi-abì tilkumu l-'izāamu 'iẓāman wa-saqąthā l-samā'u șawba l-ghamāmi.

A. F. L. Beeston.

\section{The Marquess of Zetrand}

The Rt. Hon. Sir Lawrence John Lumley Dundas, K.G., P.C., G.C.S.I., G.C.I.E. was born on 11th June, 1876. He visited Ceylon, Persia, Burma, Japan and China and travelled in Central Asia and Siberia. From 1916 to 1922 he was Governor of Bengal and in spite of Indian mistrust of a disciple of Curzon won the respect and affection of the people during a most difficult period. Though he 